\title{
THE INVERGORDON MUTINY, 1931: LONG-TERM CAUSES, ORGANISATION AND LEADERSHIP
}

On Tuesday September 15th, 1931, at 8.00 a.m. most of the stokers of the forenoon watch in the battleship HMS Valiant, under orders to sail from Invergordon for exercises in the North Sea, refused duty and prevented the ship from sailing. In the battleships Rodney and Nelson and the battlecruiser Hood, all due to follow Valiant out to sea, the crews also refused to turn to. By 9.31 a.m. the admiral commanding the Atlantic Fleet had cancelled the exercises and recalled to Cromarty Firth those ships already at sea. What was to become known as the Invergordon Mutiny had begun. In reality it was a passive protest over recently announced cuts in pay. At various times in the course of the next thirty-six hours large numbers of the 12,000 men in the twelve capital ships at Invergordon joined in the action and refused orders.

The mutiny can only be really understood in the context of post-1918 lower-deck social history. The following is an attempt to interpret the event in terms of long-run changes in the level of sailors' pay and pensions, attempts by ratings to establish a form of representation in matters of welfare, the growing collective consciousness of the lower deck consequent on this, and the Admiralty's failure to provide an adequate channel for the processing of collective grievances. ${ }^{1}$

In the weeks following the Armistice in November 1918 unrest in the armed services reached serious proportions. In the Royal Navy the principal cause for complaint was the level of pay. But for an increase of $2 \mathrm{~d}$ per day in 1917 naval pay had been unchanged since 1912 . The basic rate for an able seaman was $1 / 10 \mathrm{~d}$ per day and ratings were now insisting that this be increased by a substantial amount. Petty officers and ratings were flocking into the lower-deck death-benefit societies, organisations which

1 Most of the research for this was undertaken with the help of an SSRC award and a Visiting Fellowship at Sussex University 1973-76. 
for a decade or more had been pressing for the right to represent the sailors in matters of lower-deck "welfare". Increasingly these societies were being thought of as naval trade unions. ${ }^{2}$ In the November 1918 General Election the lower deck had already put forward their own parliamentary candidates at Portsmouth and Chatham. And if existing channels of representation proved ineffective there were those among them who were prepared to go all the way and join an out-and-out trade union. If necessary they were prepared to strike. ${ }^{3}$

The Government and the Admiralty were fully aware of the seriousness of the situation. In the aftermath of the August 1918 police strike Cabinet Ministers had been warned of the dangerous mood of naval ratings in a confidential memorandum prepared by Lionel Yexley, editor of the lower-deck paper The Fleet and for twenty years previously the leading figure in the lower-deck reform movement. ${ }^{4}$ Partly as a result of this the Admiralty appointed a committee under Rear-Admiral Sir Martyn Jerram to look into the question of pay. The committee convened in January 1919 against a background of industrial unrest and strikes actual and threatened in many sections of the labour-force. Such events could not but influence the mood of the lower deck. The Jerram Committee was unique in naval history. In a unprecedented move a number of lower-deck representatives were attached to the Committee in an advisory capacity and evidence was heard from selected lower-deck ratings. On the eve of the Committee hearings over 100 lower-deck delegates met in the Connaught Rooms in London in breach of the ban on combinations in King's Regulations, and agreed on a common programme of demands calling among other things for increases of at least $4 /$ - per day. ${ }^{5}$

So tense was the situation that the Admiralty did not wait for the

2 For a full account of the development of lower-deck societies see Anthony Carew, The Lower Deck Reform Movement 1900-1939, forthcoming. An able seaman (AB) is a fully-trained seaman, the rate being attained at about the age of 19. The next rank up is leading seaman (LS). At the time of Invergordon this rank was reached when a man was in his mid to late twenties. Above the leading seaman is the petty officer (PO), a non-commissioned rank attained in the period under consideration in a man's early thirties.

3 The possibility of a sailors' strike was pointed out by the First Lord of the Admiralty in a letter to the Chancellor of the Exchequer, September 3, 1918, Adm. 116/1603. By March 1919 a trade union for the armed forces, the Soldiers', Sailors' and Airmen's Union had been formed. Admiralty (Adm.) papers are held at the Public Record Office, London.

4 The Fleet, May 1928, p. 83. For an account of Yexley's role in securing improvements in lower-deck conditions and his extraordinary influence at the Admiralty see Carew, The Lower Deck Reform Movement, op. cit.

5 The Fleet, December 1919, pp. 196-97. 
Committee to conclude its hearings and on January 29th announced an interim pay bonus of $1 / 6 \mathrm{~d}$. It was by no means certain that the pay concession would satisfy the lower deck, and in mid February the Second Sea Lord circulated an urgent memorandum among his colleagues on the Board of Admiralty.

I desire to bring to the notice of the Board that, in my opinion, there is no doubt that an organised attempt is being made by socialist and syndicalist circles to introduce into the Navy a Lower Deck Union on Trade Union lines $[\ldots]$.

The position with which we are now faced is this: If we do nothing, there is the possibility that the Lower Deck Union will become an accomplished fact. If, on the other hand, we are prepared to allow the men a recognised means of presenting their grievances - real or imaginary - and aspirations collectively, I believe that the danger of an unauthorised Union will be averted. [...]

It is, I think, essential to provide an authorised and controlled means for the Lower Deck to ventilate its feelings. ${ }^{6}$

In view of the Second Sea Lord's warning the Admiralty announced on February 24th the institution of a Welfare Committee made up of Admiralty officials, which would meet annually and hear proposals from selected lower-deck spokesmen for improving pay and conditions of service. ${ }^{7}$ The arrangement appeared to meet the sailors' demand for a permanent channel for collective representation. The final report of the Jerram Committee issued in May proposed to fix the level of able seamen's pay at $4 /$ - per day. The interim bonus was thereby consolidated, but no more money was offered. It was a bitter disappointment to the lower deck and led to further ominous rumblings of discontent. ${ }^{8}$ But at least the newly announced Welfare Committee system would allow them to raise the issue again within a few months.

The first Welfare Committee began its work in October 1919. With regard to the basic questions of pay and pensions the men's demands were a restatement of their position before the Jerram Committee. ${ }^{9}$ But the Admiralty was now in no hurry to deal with these. The Welfare Committee had before it numerous minor requests for improving conditions of individual groups and classes of sailors, and it used these to justify the delay in producing its report. Indeed no Admiralty reply was issued until July 1920 , when it rejected the main requests on pay and pensions. And now the

${ }^{6}$ Memo of February 14, 1919, Adm. 1/8566/235.

7 Admiralty Weekly Order 737, February 24, 1919, Adm. 182/14.

8 The Fleet, June 1919, p. 90.

9 Ibid., November, p. 127. 
lower-deck representatives to the next-scheduled Welfare Committee were told that, in formulating new proposals, requests previously presented and turned down were not to be re-submitted. ${ }^{10}$ The lower-deck spokesmen, who had been hoping for an increase in pay to match the recent $12 /-$ per-week cost-of-living bonus awarded to the police and their basic weekly rate of seventy shillings, found themselves in an impossible position. ${ }^{11}$ In anger and frustration the representatives walked out of the hearings and, realising that there was no hope for a loosening of the rigid terms of reference of the Welfare Committee, the delegates suggested to the Admiralty that it should be dissolved. ${ }^{12}$

By this time many sailors could see that there was a huge gap between their own concept of how collective grievances and requests ought to be handled and that of the Admiralty. Once again men began to talk about the need for a real trade union, and letters to the editor in the newspapers at the home ports began to urge the formation of such ${ }^{13}$ In December 1920, amid fears that the more militant sailors might be falling under the influence of left-wing socialists, the Admiralty acted decisively to put paid to the wider organisational aspirations of the lower-deck movement. A fleet order was issued forbidding any attempt to amalgamate the lower-deck societies into a trade union, and the societies were categorically excluded from any welfare work. In effect they were not recognised as having any representative functions; and were merely to confine their activities to death benefit. ${ }^{14}$ The effect of this was to weaken their membership severely. Prevented from acting in a representative capacity, they had little attraction for the sailors. At the same time, knowing that the societies would be carefully watched by the Admiralty, many men made sure they kept well clear of them. ${ }^{15}$

Two years later, when the storm had passed, the Welfare Committees were revived, but in a severely neutered form. There were to be no lowerdeck representatives attached to the Committee and no lower-deck-society involvement in formulating requests at the ports. The Committee was to meet no more frequently than every second year. And the Admiralty warned that requests involving large financial expenditure were unlikely to be met. ${ }^{16}$ For ten years until 1932 the biennial ritual of the Welfare

10 Naval and Military Record, July 14, 1920.

11 The Fleet, November 1920, p. 189.

12 Naval and Military Record, August 4 and 11, 1920.

13 Hampshire Telegraph, July 2, 1920; Naval and Military Record, August 11.

14 Admiralty Weekly Order 3657, December 22, 1920, Adm. 182/19.

15 The Fleet, July 1922, p. 107.

16 Admiralty Fleet Order 3604, November 4, 1921, Adm. 182/31. 
Committee was re-enacted, unable to deal with the major economic grievances of the lower deck and arousing scarcely any interest among the ratings.

With the end of the short post-war boom it was no longer a question of securing a pay increase but of preventing cuts in pay. There were those in the Admiralty who believed that the rates established in 1919 were too high, especially where able seamen were concerned. ${ }^{17}$ In September 1922 the first hint that a reduction in service pay was under consideration appeared in the press. ${ }^{18}$ And early in 1923 the Government announced the appointment of a Committee of Inquiry under Sir John Anderson to look into the remuneration of state servants. Its report stated that the pay of ratings was too high and should be reduced. Anderson's argument was simple. It was that since there was no difficulty in recruiting men for the Service rates of pay could not be too low. The committee pointed out that an able seaman's pay was now 150 per cent above the pre-war rate and asserted that the level in 1914 had not been too low. The suggestion angered the older ratings, who remembered the hardships associated with pre-war rates and more sharply still the difficulties they had had in coping with the rising cost of living during the war years.

The proposal snapped the lower-deck societies back into life in the summer of 1923, and as the November General Election approached a vigorous campaign was waged by the lower deck against any cuts. The threat to pay became a rallying cry for recruiting men into the benefit societies once more. ${ }^{19}$ At Plymouth in October a joint committee of the lower-deck societies held a dinner at the Royal Hotel for the three Plymouth MPs Lady Astor, Sir A. Shirley-Benn and Sir Clement Kinloch-Cooke together with the Parliamentary Private Secretary to the First Lord of the Admiralty, and secured promises that each of them would oppose any cuts in naval pay. ${ }^{20}$ Lady Astor was invited to speak at society meetings. ${ }^{21}$ And during the election campaign itself the secretary of the Devonport Seamen's Benefit Society spoke at political meetings of all three parties drumming up opposition to the Anderson scheme. ${ }^{22}$

Once again the Admiralty intervened to thwart the campaign. In October a letter had been sent on behalf of the lower-deck societies to all the members of the Dockyard Committee of MPs expressing opposition to

17 Secretary to Board of Admiralty, minute. March 14. 1934, Adm. 116/2891.

18 The Times, September 11, 1922.

19 The Fleet, August 1923, p. 126; September, p. 129; April 1924, p. 62.

20 Western Morning News, October 27, 1923.

21 The Fleet, November 1923, p. 174.

22 Ibid., January 1924, p. 13. 
the pay cuts. The Admiralty reacted by sending the Chief of Staff of the Commander-in-Chief, Portsmouth, to a specially summoned meeting of the lower-deck societies for the purpose of reading out those sections of the King's Regulations forbidding combinations of sailors. The sharp warning of 1920 was dramatically re-affirmed. ${ }^{23}$ The resurgent lower-deck societies were pulled up short. And to emphasise the Admiralty's unwillingness to tolerate agitation by ratings orders were issued calling for naval officers to attend future society meetings as observers. The action served its purpose. The intervention of the Chief of Staff was a turning point. And never again would lower-deck-society membership approach the level of 1923. From here onwards their decline was steady and continuous.

Simultaneously the Admiralty also moved to prevent the lower deck from approaching Members of Parliament with their grievances. Since before the Great War the MPs representing naval constituencies had formed themselves into a committee for purposes of lobbying. The Dockyard Committee was not an official Commons body and its existence was a source of annoyance for the Admiralty, which felt that it attracted grievances from the lower deck. And for a sailor to approach an MP on a service matter was a punishable offence. The original Welfare Committee system had been devised in part to try to stop men from contacting MPs and have questions raised in the House. ${ }^{24}$ But it failed in this respect and in the early 1920's the dockyard MPs bombarded the Admiralty with questions on lower-deck affairs. Consequently, during the 1923 campaign over pay cuts the Admiralty began to consider ways of reducing the number of questions asked by MPs. It was not thought practical to try to prevent all communication between ratings and Members of Parliament, but from this point on Admiralty answers to questions asked in the House tended to be very evasive, and whenever possible the line of approach was that if ratings would use the correct service procedures to make complaints they would be looked into. ${ }^{25}$ The "correct procedure" excluded any possibility of broaching a collective grievance. Rather it involved individual ratings taking their complaints to their superior officer and then, if not satisfied, appealing over his head up the naval hierarchy. But there was not the slightest chance of ratings risking their careers by following this course and challenging their immediate superiors. The effect of the new policy was, therefore, simply to seal off another important safety valve for airing grievances.

23 Ibid., December, 1923, p. 180; Western Morning News, December 27; Report of Admiral Fremantle to Admiralty, November 1 , Adm. 1/8666/159.

24 Secretary to Board of Admiralty, minute, October 18, 1934, Adm. 116/3748.

25 Head of Naval Branch, minute, July 18, 1928, Adm. 1/8666/159. 
For the time being the 1923 pay campaign had apparently succeeded in mobilising parliamentary support against the proposed cuts. Ramsay MacDonald, the new Prime Minister, had given a commitment to maintain naval pay, and in March 1924 the Financial Secretary to the Admiralty affirmed in Parliament that as far as serving ratings were concerned their rates would not be cut. ${ }^{26}$ But the statement conveniently side-stepped the question of whether any cuts in pay were still proposed. Indeed cuts were still very much on the agenda. Under Treasury pressure the Admiralty was in the process of drafting revised pay scales and at a conference of the three armed services just nine days after the Financial Secretary's statement Admiral Sir John Kelly, the Fourth Sea Lord designate, accepted on behalf of the Navy the principle of a $9 \mathrm{~d}$ reduction in the daily rates of pay at the lowest level for able seamen. However, the War Office favoured even larger reductions in all three services and no general agreement could be reached on the details of the cuts. Successive inter-departmental committees attempted to produce a generally agreeable formula, during which time the Admiralty gradually gave in to the War Office view. ${ }^{27}$

Meanwhile the evasiveness of the politicians on the question of cuts continued. In the November 1924 General Election Stanley Baldwin made a commitment that existing rates were to be permanent, and in July 1925 Sir Bertram Falle, Conservative MP for Portsmouth North repeated the promise on Baldwin's behalf, even as cuts were still being discussed. ${ }^{28}$ Eventually, following the return of a Conservative Government, it was decided that aggregate cuts of 15-16 per cent in naval pay would be made. The Admiralty chose to effect this by reductions of $1 /$ - per day in the pay of able seamen, petty officers and chief petty officers, meaning that at the lowest level able seamen would have to bear a reduction of 25 per cent. ${ }^{29}$ No one at the Admiralty seems to have been concerned with the inequity of these percentage cuts. All appear to have been more impressed with the argument that able seamen were overpaid. There is no evidence of any high-level resistance to the cuts by the First Lord or opposition from Admiral Beatty, the First Sea Lord. All the Sea Lords concurred in the eventual revision in rates of pay which was to apply to men recruited as of October $1925 .{ }^{30}$ The acquiescence of the Sea Lords in the cuts stands in marked contrast to their vigorous opposition to and talk of resignation over

${ }^{26}$ House of Commons Debates, March 18, 1924, c. 293; The Fleet, March, p. 42.

27 Secretary to the Board of Admiralty, minute, March 14, 1934.

28 Hampshire Telegraph, July 31, 1925.

29 Secretary to the Board of Admiralty, minute, March 14, 1934.

${ }^{30}$ Admiralty Fleet Order 2858/59, October 3, 1925, Adm. 182/42. 
the Treasury's call in the same year for cuts in spending on new cruisers. Beatty, the one man at the Admiralty with the stature to stand up to the Cabinet, who regarded his fight against cutbacks in spending on ships as the most important battle of his life, apparently accepted without demur the reduction in pay. ${ }^{31}$

The policy of introducing two rates of pay for men doing the same work was a long-term prescription for trouble. Men already in the Service were to be reprieved, but the Admiralty no longer regarded the 1919 rates as sacrosanct, despite the fact that it had earlier referred to the Jerram increases as permanent. ${ }^{32}$ Now the official announcement of the new scale noted that it was to be "clearly understood that men are not entitled to a right of any rate of pay or any emolument under existing scales". ${ }^{33}$ The two-rate system meant the gradual introduction into the Service of men who would not be able to afford the standard of living of their mess mates, who would be unable to meet their mess bills, and for whom marriage would be financially impossible. It would engender jealousy, and sooner or later there would be pressure to cut the pay of men on the 1919 rates. As the decade wore on and as the proportion of post-1925 men increased the pay issue was to become a serious problem. But now there was no vocal lower-deck movement, no vigorous campaigning to alert the country, and no ready access to sympathetic MPs. All that remained of a once-virile reform movement was a handful of ailing death-benefit societies forbidden to speak out, and a Welfare Committee system to which nobody paid any attention.

To a keen observer the effect of the cuts on material standards of living could already be seen in the late 1920's as the first generation of post-1925 recruits began to work their way through the Service. ${ }^{34}$ NAAFI revenue was down: in 1925 men had spent on average $2 \frac{1}{2} 2$ per day on beer, but by the early 1930's expenditure on this item had fallen by 40 per cent. ${ }^{35}$ The Royal Naval Benevolent Trust, the sailors' own hardship-relief organisation, was having difficulty in raising funds from the lower deck, while at the same time increasing demands were being placed on its resources by needy sailors and their families. ${ }^{36}$ Men under the age of 25 were not eligible

31 R. R. James, Memoirs of a Conservative, J. C. C. Davidson's Memoirs and Papers 1910-37 (London, 1969), pp. 206-15: The Times. July 22, 1925.

32 Admiralty Weekly Order 2359, August 5, 1920, Adm. 182/19.

33 Admiralty Fleet Order 2858/59. October 3, 1925.

34 The Fleet, February 1930, p. 21.

35 Ibid., August 1929, p. 134; June 1934, p. 92.

36 Ibid., August 1929. p. 134. 
for the 7/--per-week service marriage allowance, and consequently in the changed circumstances the worst-off ratings were those able seamen on the 1925 pay scale who had married while still under 25 . Out of a total basic weekly pay of $£ 13 / 2 \mathrm{~d},{ }^{37}$ plus $1 / 8 \mathrm{~d}$ lieu payment for rum if he happened to be abstainer, he would have to support a wife and a home as well as maintain himself. A typical family budget might involve $12 / 6 \mathrm{~d}$ for rent, $3 /$ - for light and cooking, 2/6d for coal, $2 /-$ for insurance, $5 /-$ hirepurchase payment on furniture and $1 /-$ for the boot club. Even without expenditure on food, clothes or amusement the weekly bill would hardly be less than twenty-six shillings. ${ }^{38}$

But in addition the sailor also incurred bills in the Service. The cost of subsistence varied depending on location and ship. The more modern warships had "general messing", an arrangement under which all meals were centrally cooked and served to the men. This system involved little additional expenditure on extra rations and for this reason alone was preferred by most men. But the traditional system of victualling the lower deck, still widely practised, was for them to be issued with basic rations only which they prepared themselves. In addition they received a messing allowance with which to buy food items of their choice from the canteen. The system was preferred by some men who set great store by their food, but it also tended to involve larger expenditures and ratings would commonly have to meet bills in excess of their messing allowance from their own basic pay. An average mess bill could run to $10 \%$ - per month, but on the West Indies or China stations, where the cost of food at the canteen was higher, monthly bills of $25 /$ - and $18 /$ - on "standard ration" ships were commonplace. Clearly there was no way that younger men on the new rates could afford this and maintain a home in the United Kingdom. ${ }^{39}$ Because of this some men would ask to be excused a draft to certain ships where mess bills were known to be high. ${ }^{40}$

Another factor was that rental accommodation in the naval home ports was extremely costly. The average rent for a room was $11 /$ - per week. Some ratings lived in unfurnished rooms and bought furniture on hirepurchase to avoid the high cost of furnished accommodation, but then the hire-purchase commitment was often crippling. As a result many men serving in home waters chose to live away from the naval ports, perhaps in

${ }^{37}$ Assuming the seaman had served 3 years' man's time - i.e. from the age of 18 .

38 Report of Committee of Enquiry into Hardships. Portsmouth. September 22, 1931, Adm. 116/2891.

39 Ibid.

40 Lt. Commander J. H. Owen, Insubordination and Mutiny in the Navy: Staff Monograph, Vol. II, ch. 3, p. 8, Adm. 178/133. 
their wife's home town. But then there was the problem of rail fares on leave. From Scapa Flow or Rosyth to towns in Southern England a return rail ticket could cost as much as £4. In many cases it was a question of saving up by strict economy and self-denial over a period of months to make one return journey home. Even the return fare from Plymouth to London was sufficiently high as to prevent many Londoners from going home on leave more than once every two months. ${ }^{41}$

The dismal family circumstances of men on the 1925 rates was described in a report by the Commodore of Portsmouth Barracks some years later.

As regards food, tinned milk, $3 \mathrm{~d}$ for bones for making soup, cheap bits of frozen meat, bread and butter. tea, cook shop food, appear to be the general mode of living, while vegetables are only a weekend affair. When a pair of boots has to be mended some other thing has to be done without.

So hard pressed were some families in rented rooms that they would share Sunday dinner with the householder in order to spread the cost around a little. $^{42}$

In these circumstances it is not surprising that the post-1925 entries looked to the future with some trepidation. In February 1930 The Fleet published a letter to the editor by one young sailor.

Pay never worried me: it does not do so much now. But I am looking ahead. I can see a growing bubble of discontent bursting in a few years' time when we think how impossible it will be for an A.B. or L.S. with the new scale of pay to support a wife and family and keep them respectable and pay for rent or rooms. [. . . I I cannot see it possible to support a wife. etc., on that: to do so a man would have to give her every penny of his pay. Even a P.O. or Chief on new rate would have to scrape. Something will have to be done about it sooner or later. ${ }^{43}$

It was a common complaint that in their recruiting drives among the unemployed the Admiralty made little effort to explain that rates of pay were now lower. The result was that men were joining the Service without fully realising how relatively disadvantaged they were going to be. ${ }^{44}$ And later in the year a correspondent to The Fleet declared that the time had come for post-1925 entries to make themselves heard throughout the Navy. ${ }^{45}$ In spring 1931 the Admiralty turned down a request made in

41 Report of Committee of Enquiry into Hardships, Plymouth, September 22, 1931 , Adm. 116/2891.

42 Report of Commodore. Portsmouth Barracks, July 1934, Adm. 116/2891.

43 The Fleet, February 1930, p. 21.

44 Ibid., April, p. 63.

45 Ibid., September. p. 169. 
Parliament that the qualifying age for marriage allowance should be reduced to 22, and during the debate on the Navy Estimates Mr J. Kinley was led to remark: "No one need pretend that the Navy is a happy family of very happy men, who would not leave if they had an opportunity. No one need pretend that the Navy is satisfied." 46

Generalisations about the level of contentment among older ratings in the late 1920's are hard to make. Naval conditions in the 1920's were infinitely better than in pre-war years. But this perhaps was not the comparison that men made. They judged their conditions in terms of what seemed reasonable to expect, and now their expectations were higher. In the wake of the 1919 pay increases sailors enjoyed a modest improvement in their standard of living. Lower-deck families moved from single-room accommodation to two rooms, and from two rooms to small rented houses. ${ }^{47}$ There was a certain amount of dissatisfaction with the Welfare Committee system and the lack of any effective channel to forward general claims for improvements in service conditions. The amount of foreignservice duty rankled with some married men..$^{48}$ Others found the routine of the peace-time Navy irksome. But at the bottom it was the bearing that certain peace-time conditions had on material standards of living that was of most importance. The Navy in peace-time was no place to obtain quick advancement, and by the late 1920's there was a marked stagnation in promotion prospects. ${ }^{49}$ In the early 1920's an able seaman could expect to be promoted to leading seaman with a higher rate of pay at the age of 24 , but by the early 1930's the average age at promotion was 27 . Similarly, petty officers had formerly reached the rank aged 28 , but now the normal age on promotion was 32 . By the early 1930's it was not uncommon for a quarter of a ship's able seamen to have more than 12 years' service in, and large numbers of older able seamen implied a discipline problem for the Service. They were old hands, they knew the ropes and were not going anywhere from a career point of view. Some of them would be older than the petty officers over them and consequently not easily kept in line. ${ }^{50}$ These were the men whose pay was soon to be cut. And some of them had already had their pension prospects undermined.

Pensions were only payable to men who signed on for and completed a further 10 years' service after their initial 12 years. The Jerram Committee

46 House of Commons Debates, March 11, 1931, c. 1347.

47 The Fleet, March 1924, p. 40.

48 Owen, Insubordination and Mutiny, Vol. II, ch. 3, p. 9.

49 The Fleet, August 1929, p. 134.

50 Report of Admiral Kelly, November 9. 1931, Adm. 1/8761/240. 
had fixed the rate of pension at $11 / 2 \mathrm{~d}$ per day $-10 \frac{1}{2} \mathrm{~d}$ per week after 22 years. In March 1930, in a further quest for economy, the Admiralty announced that the pension rate would henceforth be reduced to $8 \mathrm{~d}$ per week. This meant that men on 1919 rates of pay who began their second period of service after March 31st, 1930, would be paid 25 per cent less pension than men on identical rates of pay who had already begun their final ten years. ${ }^{51}$ Another differential was being introduced into the lower deck. It was a serious blow for men who intended to make the Navy a career. For those already in their second period it was a narrow let-off. They could take comfort in the knowledge that they had already entered into an agreement to serve for twenty-two years with a 1919-level pension at the end, and that agreement was binding - or so they thought.

In 1931, as the economic depression deepened, the Labour Government set up a Committee on National Expenditure under the Chairmanship of Sir George May. The May Committee Report published on July 31 st urged extensive pruning of state expenditure including wage cuts for civil servants, teachers, the police and the armed forces. ${ }^{52}$ As far as the forces were concerned the Report recommended that the 1925 rates be applied to all men. "No officer or man serving His Majesty", argued the Committee, "has any legal claim to a particular rate of pay". ${ }^{53}$

On July 21 st, 1931, the men of the Atlantic Fleet had begun their seven weeks' summer leave. When on July 31 st the May Report was made public they had plenty of time to study its implications. Newspapers in the home ports and the left-wing press made much of the proposal to enforce 1925 rates all round. ${ }^{54}$ Throughout August the threat of service pay cuts was kept alive. ${ }^{55}$ Not only would the 1925 rates of pay apply all round, but the 1930 pension rates would be generally introduced throughout the Service along with cuts in clothing allowances and lieu payments. The Communist Party made a special effort to carry its propaganda to the Navy. In Chatham during Navy Week, the Service's annual public-relations recruiting exercise, the Young Communist League staged public meetings which were attended by some ratings in uniform. ${ }^{56}$ And Harry Pollitt, the

51 Journal of the Royal United Service Institute, May 1930, p. 419.

52 Committee on National Expenditure Report [Cmd 3920].

53 Ibid., p. 39.

${ }^{54}$ Portsmouth Evening News, July 31; Western Morning News, August 1; Daily Worker, August 6.

55 Portsmouth Evening News. August 26; Daily Worker. August 7 and 19: Hampshire Telegraph. August 21 and 28 .

56 Daily Worker, August 6. 
Party Secretary, went down to Chatham to address one outdoor rally at which a reinforced naval patrol was called out to clear away uniformed men in the audience. ${ }^{57}$

The extent to which ratings were aware of the implications of the May proposals is a matter of some significance in understanding the build-up to, and the nature of, the mutiny. The Admiralty's subsequent hunt for ringleaders and outside agitators reflects a view commonly held in sections of the Service that the generality of lower-deck ratings were incapable of staging such a protest unaided, and that the action had elements of a deliberate attempt to subvert the Navy. Admiral Kelly's official report on the mutiny indicates his firm belief that there was a leakage of the Government's intention to implement the May proposals and that this spawned secret lower-deck discussions on the subject. ${ }^{58}$ The implication is that sailors had somehow failed to digest information that was readily available from the press and radio. This grossly underestimated the lower deck's ability. The fact is that there was no leak. The reality was less dramatic, less sinister, but no less dangerous from the Admiralty point of view. The May Report had apparently been studied more carefully by the men than by the officers. The vast majority of lower-deck ratings were men who had joined the Service before 1925. Many of them were veterans of the Grand Fleet and were fully conscious of the agitation that had led up to the 1919 pay awards. Some had experience of collective organisation in the lower-deck societies prior to their demise and had been active in the campaign against the Anderson proposals in 1923-24. These men had watched with more than a little interest over the years as the fate of naval pay had been discussed and reviewed by politicians and committees of enquiry. They knew first-hand what sort of standard of living 1925 rates would mean, and they viewed the 1919 pay scale as something that had to be defended. A temporary sacrifice of income shared equally by all sections of the community to overcome the immediate economic crisis was perhaps acceptable, but any permanent departure from the principle of the 1919 rates had to be resisted.

On September lst The Fleet carried an anonymous letter to the editor from a rating in the Mediterranean Fleet, whose tone captures well the prevailing mood of apprehension and bitterness and the hint that action might be expected from the men should the full 1925 cuts be enforced. Addressing the editor, Yexley, the correspondent wrote:

57 Ibid., August 7.

58 Report of Admiral Kelly. 
What I want you to realise is that you are not going to be permitted to rest on your laurels, for it seems that a bigger problem is confronting the Lower Deck in the near future than ever occurred in 1919. [...]

There has recently been published the recommendations of the Royal Commission on National Expenditure, and under the "Services" heading there appeared the recommendation that the pay of all Naval personnel should be reduced to the 1925 rate. We all realise that such a recommendation may not be adopted, but we all rather fear that it might. We all sincerely hope that the many solemn promises that Parliament made to us in 1925 will not be broken, but so very many promises, not necessarily appertaining to the Navy, have been broken that we all feel somewhat dubious of getting better luck.

It is a bit too premature to get pessimistic about it, I will admit, but I believe that just at present this matter is exercising the minds and discussions of the Lower Deck to the almost total exclusion of anything else. We are all wondering what will happen if the powers that be do adopt such a course. Will it be a case of Hobson's Choice - like it or lump it? Will we get the opportunity to resist such an obviously unfair measure, and if so will the existing Welfare machinery be strong enough to deal with such a job? I for one doubt it. [...]

Did any of the commissioners visit a sailor's home to see how his pay is spent during the course of their enquiry? Did they ever visit and live with sailors aboard a small ship to see how that pay is earnt? Obviously they didn't [....].

If they want to know where expenditure in the Navy can be reduced they have only to ask the average A.B. - if they can get him to talk; but in the meantime we are all asking, What is going to happen - If? ${ }^{59}$

The letter indicates that even in the Mediterranean there was no shortage of information and discussion among the lower deck, but that fleet was now dispersed in small groups on its annual summer cruise of the Eastern Mediterranean. The ratings of the Atlantic Fleet were less isolated during their summer leave at home. They were in a position to discuss the meaning of the cuts and could hardly have failed to see that other sections of the community were organising to resist them. Unemployed workers in Bristol had staged a protest demonstration at the TUC against proposed reductions in unemployment benefit. A similar demonstration had occurred in London, while teachers and policemen indicated that they were not prepared to accept pay cuts without protest. ${ }^{60}$ By the end of the summer leave period a consensus had almost certainly formed among important sections of the lower deck around the view that if the full 1925 cuts were introduced the men would refuse to accept them. They were drawing on

59 The Fleet, September 1931, p. 169.

60 Ernie Trory, Between the Wars, (Brighton, 1974), p. 26; Barry Duncan, Invergordon '31 (Southampton, 1976), p. 13. 
their collective consciousness of the 1919 campaign. As in 1919, it would be "up to the fleet" to take the initiative. But for the time being the men were keeping their cards close to their chest. ${ }^{61}$

In any case there were no viable channels of protest open to the men within the law. Had the lower-deck societies been operating vigorously as they were before 1923 , it is likely that they would have initiated a press campaign against the cuts, thereby drawing public attention to the seriousness of the situation. But this route had been closed off. Equally there was no approach to the Members of Parliament in the home ports. Admiralty policy now was for the Parliamentary Secretary to write to any MP who tabled a question on lower-deck matters asking him to be good enough not to proceed with it. ${ }^{62}$ In 1929 a rating from the Repulse had written to his constituency MP for the Isle of Thanet to complain about leave arrangements. The author of the letter was traced by the captain and sentenced to 28 days' detention. This prompted Will Hall, Labour MP for Portsmouth Central, to ask in the House of Commons about the propriety of the sentence. The Admiralty were unwilling to commit themselves on such a sensitive issue and reluctant to court adverse publicity in public discussion of the case. After some weeks of indecision the Parliamentary Secretary decided that "Hall should be spoken to privately and not answered by mail." ${ }^{3}$ Hall appears to have been satisfied with his private, verbal reply. The question was conveniently swept under the carpet, and the lower deck were left to draw the appropriate conclusion.

Not surprisingly, then, no approaches were made to MPs to appraise them of lower-deck feelings. Only one public figure appears to have sensed that something was in the wind and tried to alert the Admiralty. W. A. Appleton, General Secretary of the General Federation of Trade Unions, had long-standing contacts with activists in the lower-deck movement. $\mathrm{He}$ had worked closely with a number of lower-deck societies at the end of the war and in 1919 had vigorously supported the claim for a pay increase. On September 9th, less than a week before the outbreak of mutiny, he had questioned Admiral of the Fleet Lord Wemyss as to the contentment of the lower deck and advised him to "watch the Fleet". This cryptic warning was duly passed on to the First Sea Lord, but to no avail. ${ }^{64}$ What the basis of his

61 Report of Director of Naval Intelligence, May 1932, Adm. 178/110. This interpretation is supported by Commander Harry Pursey, who was the commander's assistant on the flagship Hood at Invergordon. Interview, January 23, 1974.

62 Head of Naval Law, minute, December 12, 1934, Adm. 178/90.

63 Parliamentary Secretary, minute. September 20, 1929, Adm. 178/90; House of Commons Debates, July 24, 1929, c. 1314.

64 Report of Director of Naval Intelligence. 
information was, a direct approach from someone in lower-deck circles perhaps or simply an opinion based on a long-time, intuitive understanding of lower-deck ways, is not clear. ${ }^{65}$ But his feeling of unease was in marked contrast to the apparent lack of awareness on the part of the Admiralty of what lay in store.

The long-term causes of the mutiny were reinforced by more immediate factors. These have been well documented by David Divine and include the Admiralty's casual approach to the prospect of pay cuts, its failure to prepare the lower deck for what was in store and its generally poor communications with the Atlantic Fleet during this episode. ${ }^{66}$ It is generally agreed that the Board of Admiralty was a weak one. ${ }^{67}$ Neither the First Sea Lord, Field, nor the Second Sea Lord, Fuller, were impressive figures. Field was also in poor health and at crucial periods prior to the mutiny he, along with other members of the Board, was on leave. ${ }^{68}$ The Admiralty did not present any strong defence of the existing rates of pay when representatives met the May Committee. Nowhere is there any evidence that it weighed the implications of the cuts very seriously or considered action to prevent them. Certainly there was never any suggestion that the Board would resign. ${ }^{69}$ Throughout most of the crisis the Sea Lords scarcely met as a body, and Divine is correct to conclude that "This was in a measure a Board without real corporate existence."70

Over and above this the Admiralty was dogged by ill-fortune, though its proneness to accident may also be put down to bureaucratic bungling. On the eve of the fleet's departure from home ports for Invergordon the commander-in-chief, Sir Michael Hodges, was taken ill and command was temporarily transferred to Rear-Admiral Tomkinson in the Hood. Tomkinson was a relatively junior admiral in his first independent command. He was only told of the impending pay cuts hours before sailing for Invergordon and was given no special briefing as to their implications. ${ }^{71}$ On the other hand it was the Admiralty's intention that commanding officers generally should be briefed on the background to the economies so as to be able to explain them to the men. A letter designed

${ }^{65}$ Ibid.

66 David Divine, Mutiny at Invergordon (London, 1970), pp. 67, 207, 209. See also Stephen Roskill, Naval Policy Between the Wars. II (London, 1976), ch. 4; Commander Harry Pursey, "Invergordon - First Hand, Last Word". in: Naval Review, April 1976.

${ }_{67}$ Stephen Roskill, Hankey: Man of Secrets, 1919-31 (London, 1972), II, pp. 498, 509.

68 Divine, Mutiny at Invergordon, op. cit., p. 81.

69 Ibid., p. 83.

${ }^{70}$ Ibid., p. 87.

71 Ibid., pp. 94-95. 
to convey this information was prepared on September 10th, while the Atlantic Fleet was in passage north. It was an unfortunately-worded, long-winded letter, which sought to justify the cuts in terms of the 1923 Anderson Committee's finding that ratings' pay was too high. It also spoke of the prevailing rates as a "concession". ${ }^{72}$ The text was signalled to overseas units, but copies to ships in the Atlantic Fleet were sent by surface mail. In the event most ships had not received the letter when the fleet anchored at Invergordon on Friday September 11th. Moreover, the copy intended for the commander-in-chief was delivered not to Tomkinson in the Hood but to the flagship, HMS Nelson, which was still at Portsmouth awaiting the recovery of Hodges. ${ }^{73}$ Indeed Tomkinson did not become aware of its existence until Nelson belatedly joined the fleet on the Sunday evening and after the first signs of lower-deck unrest had become visible.

Although official information was lacking, news about the pay cuts began to filter piecemeal onto the ships on their arrival at Invergordon. Friday's papers carried news of the main proposals in the previous day's budget speech by the Chancellor of the Exchequer. With regard to service pay the information was incomplete and at times contradictory, but some papers indicated that the 1925 rates were to apply all round. ${ }^{74}$ HMS Rodney was one of the ships to have received the Admiralty's explanatory letter, and on Friday evening the captain addressed his crew on the subject of pay cuts in the sense of the letter. He pointed out that if they had any complaints they should process them through the regular service channels. However, the suggestion was not well received. Ratings had no confidence in the regular channels. And many appear to have been of the opinion that only drastic action would make any difference. ${ }^{75}$ But the first real sign that the situation might soon erupt occurred that night 150 miles south at Rosyth, where the destroyer flotilla was based. They too had received the Admiralty's warning letter, and in the course of a rowdy evening in the naval canteen ashore the men's NAAFI representative got up and recommended resistance to the cuts, but was prevented from going on by the shore patrol. ${ }^{76}$

The next 24 hours, during which half the men of the fleet were free to go ashore at Invergordon, provided an opportunity for them to compare

\footnotetext{
72 Admiralty Letter CW 8284/31, September 10, 1931, Adm. 1/8747.

73 Divine, Mutiny at Invergordon, pp. 108-09.

74 Daily Express and Scottish Daily Record, September 11.

75 Report of Captain P. M. Bellairs, September 18, 1931, Kelly Papers, National Maritime Museum.

${ }^{76}$ Report of Commander (D), quoted in Owen, Insubordination and Mutiny, Vol. II, ch. V, p. 45.
} 
notes, work up fears and exchange reactions. This was the time when the idea of resistance to the cuts first began to take shape in the minds of many sailors. On the Saturday afternoon men from all ships went on shore leave. A sizeable contingent landed from Rodney and some went to the naval canteen, where the shipboard discussions continued. ${ }^{77}$ This was the first occasion that men from different ships had met since rumours of the cuts began to circulate widely, and Rodney ratings, having already been addressed by their captain, were able to speak on the subject with more authority than most. On board in the evening the views of ratings continued to be canvassed and in the Repulse a small meeting of men was observed on the forecastle. ${ }^{78}$

By late Sunday morning the entire fleet had full confirmation of the new pay scales, but from the Sunday papers rather than the official Admiralty fleet order. In spite of the warning of the May Report six weeks earlier the announcement that the 1925 rates would apply across the board came as a deep shock. The Admiralty had failed to prepare the men for this; the size of the cuts was far greater than anticipated; they hit hardest the lower ratings, and they were out of proportion to those imposed on teachers, policemen and other public servants. They were also to take effect within a mere couple of weeks, leaving men with no time to adjust their domestic budgeting. Pension rates too were to be cut by up to 25 per cent, a clear breach of contract, and an indication that perhaps the pay cuts themselves were to be permanent and not just a temporary measure.

The general reaction among men was that they had been betrayed by the Admiralty and they were furious with rage. ${ }^{79}$ Those most affected were the older, married men, staid hands, perhaps with children. The average age of those most deeply implicated in the subsequent action was 28 , which meant that they had joined as boy seamen in 1919.80 From this point on they began to assert themselves on the lower deck. Petty officers made themselves scarce and the younger ratings were kept out of it, accused of letting the others down by joining up on lower rates. Pay was discussed whenever two men were together, on the mess deck or shuffling about on the forecastle. And in the course of the next 36 hours of debate and argument the bulk of the lower deck was won over to the view that the cuts had to be fought by one means or another. Gatherings of liberty men in the shore canteen such as had occurred on Saturday played a part in firming

77216 men from Rodney landed. Report of Captain Bellairs; letter from ex-CPO Telegraphist C. Beecroft, October 18, 1973.

78 Report of Captain Cochrane, September 19, 1931, Kelly Papers.

79 Interview with ex-Chief Blacksmith S. Rammell, April 1974.

80 Owen, Insubordination and Mutiny, Vol. II, ch. IV, p. 3. 
up this resolve. It was important for men to know that their strong feelings and reactions were shared by ratings in other ships. Even to discuss the possibility of collective action in a service where such behaviour could never be undertaken lightly was to help fortify those of fainter heart. Yet the "canteen meetings", as they subsequently become known, have been accorded more importance than they really warrant.

The idea that the meetings were something more than just gatherings of men in the canteen is closely related to the view that there must have been central leadership to mastermind the mutiny. While denying the existence of any overall leadership, Divine suggests that the meetings were more structured and representative than in fact they were. He talks of the men at the Saturday gathering forming "a quorum" and going on to issue "a summons to a mass meeting on the Sunday". Likewise the Monday meeting was called to allow "amendments" to the "plan" adopted on Sunday. ${ }^{81}$ Within the Admiralty and security intelligence it was assumed that the mutiny was organised at these meetings, and their subsequent investigations focussed on the role of supposed leaders and outside influence by civilians. But this approach ignores the sheer difficulty of organising a general mutiny. As George Hill, one of the most prominent activists, himself points out,

Ships are very insular, and no one outside the ship need know what we do or don't do unless they are told. In the light of that remark it should be understood there is a vast difference between a ship mutiny and a fleet mutiny. With a few exceptions single ship mutinies are referred to as "domestic affairs".

An individual ship knows the mind and intentions of everyone involved. You know when to start and when to stop.

In the fleet you can only hope that the intentions of ALL other ships involved will be maintained. There is no sure way of knowing. This automatically ruled out any "lead ship" as such, or more important an overall leader in a lead ship, who as circumstances develop can issue a directive to all other ships. So the question of who led the mutiny does not arise $^{82}$

Admiral Kelly's official report lends support to this view, arguing that "though it [i.e. steps to prevent the canteen meetings] might have postponed for a short time, it would not have avoided the inevitable outbreak." 83

81 Divine, Mutiny at Invergordon, pp. 110-13.

82 Letter of August 14, 1974. The same point is made by ex-AB George Day, who was prominent among the mutineers in the Valiant, interview of August 1976.

${ }_{83}$ Report of Admiral Kelly. 
On Sunday the "canteen meeting" lasted as long as the bar was open, from 2.00 p.m. to 8.00 p.m. Some sailors had been in the canteen from early on, and it began to fill up towards the end of the afternoon when football matches in the adjoining recreation ground ended. ${ }^{84}$ The canteen was a large building capable of seating several hundred ratings around tables. By evening between 200 and 300 men were present. ${ }^{85}$ The talk was all about pay cuts; feelings were running high; a riotous situation developed between 7.00 p.m. and 7.30 p.m. with glasses smashed and men beginning to speak out in favour of resisting the cuts. A number of ratings mounted the tables and tried to address the assemblage. When the shore patrol arrived to restore order, men from the Norfolk, Rodney and Warspite were observed attempting to make speeches from the tables. According to the patrol's report it was so noisy that it was impossible to hear clearly any of the speeches. ${ }^{86}$ Among those who claimed, or were reported, to have spoken were AB George Day from Valiant, AB Cyril Bond from Rodney, AB Len Wincott from Norfolk, Telegraphist Stephen Bousefield, Stoker Tom Winstanley and Marine Charles Hall from Warspite, and Leading Seaman Charles Spinks from Hood. ${ }^{87}$

Whether the speeches were heard or not, they were in themselves an act of defiance which fuelled the mood of opposition, and this was their real importance. Claims that the meeting adopted representatives from each ship with responsibility for reporting back at a subsequent meeting, set up a committee to organise the mutiny, and even fixed a code of signals can be discounted. ${ }^{88}$ Liberty men would naturally tell their messmates about what had happened ashore. Confirmation that other ships' companies felt as strongly as themselves about the cuts was an important factor in cementing the solidarity of the ratings. Back on board further discussions took place on the forecastle and messdecks. There was considerable support for some form of protest action and the most effective form of action was to refuse to put to sea. It would have to be done in a concerted fashion, and since there could be no overall direction of the action this

84 The idea that all men who were free to do so made for the canteen for a meeting (see Len Wincott, The Spirit of Invergordon (London, 1931)) is not borne out by the facts. For example, twice the number of ratings from Rodney had landed the previous day. If canteen discussions were of importance for the crew of Rodney, it seems probable that Saturday's gathering was more significant than Sunday's. Report of Captain Bellairs.

${ }_{85}$ Owen, Insubordination and Mutiny, Vol. II, ch. IV, p. 3.

86 Report of Gunner F. J. Wood, officer of the Warspite patrol, September 13, 1931, Henderson Papers, Imperial War Museum.

87 Day, interview of August 1976; Wincott, The Spirit of Invergordon; Wincott's current claim is that he was the only speaker, interview of July $24,1974$.

88 Owen, Insubordination and Mutiny, Vol. II, ch. IV, p. 4. 
automatically meant that the "downtools" would have to be when the bulk of the ships were due to sail. But at this point the full sailing programme for the week was not known.

The events in the canteen on the Sunday evening caused Tomkinson to wire the Admiralty late that night that there had been a disturbance caused by one or two ratings trying to make speeches about the pay reductions. However, the signal went unanswered and, as Divine indicates, in the course of the next thirty-six hours the Admiralty failed to heed the growing signs of a deteriorating situation at Invergordon. Throughout Monday belated attempts were made by the captains of various shipts to explain the cuts to their crews along the lines of the Admiralty's warning letter, which had now arrived. But their strictures against taking any irregular action, and especially the exhortation to process complaints through the normal channels, were, if anything, counterproductive. ${ }^{89}$ As Rear-Admiral Tomkinson later reported to the Admiralty,

There was another important factor in the subsequent spread of the trouble, viz. the conclusion which rapidly became prevalent, that the ordinary Service channels for complaints were in this case valueless, and that the men had no other course than the one they took. [...]

The more the officers urged upon the men the futility of their action and encouraged them to resort to the proper Service methods the more did it appear to many who had hitherto been opposed to the outbreak that the proper Service methods would have no effect and that the only method to secure a real consideration of the complaint was that which had been adopted. ${ }^{90}$

The lack of adequate channels for processing collective grievance was now plain for all to see.

Shore leave after tea on Monday again provided an opportunity for men to gather in the canteen. Large numbers went ashore. More Rodney ratings landed than at any time during the weekend. ${ }^{91}$ Even 65 men from Repulse, anchored a couple of miles away at the far end of Cromarthy Firth, made the journey to Invergordon despite their captain's warning to have nothing to do with "canteen agitation". This time there was no drunkenness. Men who were not normally canteen patrons went along to join in the talk about pay. But the discussion was no more organised than the previous night. The

89 In the course of Monday September 14 the pay cuts were explained to the men by the captains of Hood, Repulse, Dorsetshire, Norfolk, York and Adventure.

90 Report of Proceedings September 11-16, 1931, Senior Officer Atlantic Fleet, September 24, 1931, Kelly Papers.

91 The following narrative is based on the reports of the various ships' captains, except where stated. 
"meeting" was more a series of meetings; men from the same ship sitting in groups around two or three tables pushed together. There were, perhaps, 30 such meetings going on at once and many men had their say. ${ }^{92}$ Sailing orders for the week were now known and the idea that made most sense was to refuse to go to sea next day when the bulk of the big ships were due to sail. The gathering was broken up shortly after 6.45 p.m. when the shore patrol arrived, but discussion continued in some confusion among ratings in the recreation grounds and later in the canteen again before men finally moved back to their ships. ${ }^{93}$

As ratings returned on board there was now a mood of open defiance. Meetings were held by ships companies to agree their individual plans. On the Hood, Nelson and Repulse large meetings of men were held openly on the forecastle, and in Norfolk on the recreation deck. Valiant followed by Hood, Rodney and Nelson were due to sail in the morning between 8.00 a.m. and 10.00 a.m. If Valiant refused to sail it was generally agreed that the rest would "chuck their hands in".

It may be that some ratings from Rodney attempted to signal confirmation of their intent to other ships. A number of captains leaving the Hood at 10.00 p.m. after a dinner party noticed much signalling from her. Earlier on the Valiant at about 9.20 p.m. a nervous chief yeoman of signals reported that a large body of ratings had tried to gain access to the signal deck to make an OK signal to Rodney, though the signal officer felt sure that no signal had actually been made. ${ }^{94}$ Reports of illicit signalling at Invergordon are an integral part of the close-conspiracy interpretation of the mutiny. If the action was being centrally orchestrated, there would have to be a method of communication. Some have been all too ready to believe that a secret code of signals had been worked out. A 24-inch light shining in the sky on Monday night apparently from the direction of Rodney was taken by Lt. Robert Elkins of Valiant to have some hidden significance. Apparently he did not connect this with the fact that at that very time normal search-light exercises were taking place on the Hood, the next ship in the line to Rodney.

Few ratings reckon to have seen any visual signalling, and altogether the idea that messages of any substance were transmitted from one ship to

92 This point is made by Day, interview of August 1976; Rammel, interview of April 1974; ex-AB Fred Copeman, interview of January 1974: ex-Stoker B. Jowett, interview of December 1973. All were present, but none of them normally spent time in the canteen.

93 Report of Lt. R. Elkins, Officer Commanding Shore Patrol, September 25, 1931, Kelly Papers; Roskill, Naval Policy Between the Wars, II, op. cit., p. 102.

94 Diary entry by Lt. Commander Charles Drage, Signals Officer, September 14, 1931. private papers of Commander Drage. 
another at any time during the mutiny lack credibility. Following the incident of Monday night Lt. Commander Drage in the Valiant gave specific orders that there was to be no "yeoman to yeoman" signalling, 95 and similar instructions would have been given on other ships. It would still be possible for a man shielded by other bodies to make an illicit signal by flashing light unobserved from the forecastle of the ship, but the problem was that anybody at the receiving end with a knowledge of morse, including ships' officers, could read such a signal. In any event eight of the twelve ships at Invergordon were moored in line astern with their forecastles all facing the same direction. In this position it would be difficult to signal from forecastle to forecastle except for a short period when the tide turned and ships swung round at anchor. As for wireless signalling, much the same argument applies. An illicit signal could be sent, but all signals would be received on every ship and the transmitter could not know who might pick it up. In the middle watch wireless telegraphists would often transmit an unauthorised "dit" just to test the receiver and to see that fellow operators were still awake. But it seems highly unlikely that at any stage there was anything more than this. ${ }^{96}$ The fact is that from Monday night onwards ships were effectively on their own and had to improvise their refusal of duty as best they could.

Before midnight on Monday Tomkinson wired the Admiralty: "Further disturbances took place among libertymen landed at Invergordon this evening. Liberty men have all returned on board but there is considerable unrest among a proportion of lower ratings." 97 In the early hours of Tuesday morning, with no reply to his earlier messages, he signalled the Admiralty: "Having received reports from Flag and Commanding Officers I am of the opinion that it may be difficult to get ships to sea for practice this morning Tuesday."98 Again there was no reply. In effect Tomkinson was being left by the Board of Admiralty to sort out the matter by himself.

On Tuesday morning, September 15th, the various decisions taken on the messdecks the previous night soon became apparent. At 6.00 a.m., the normal time for seamen to turn to and scrub decks, only the Hood, Norfolk and York could report a full muster. In Valiant the petty officers and a few leading seamen presented themselves for duty but no seamen turned to. Only 75 of Rodney's seamen were present. 60 of Nelson's seamen were absent, 57 were missing on Dorsetshire, while in Adventure the hands fell in

95 Ibid.

96 Letter from ex-CPO Telegraphist C. Beecroft, November 25, 1977.

97 Invergordon - Copies of Signals, Henderson Papers.

98 Ibid. 
reluctantly. Despite the patchiness of the response it was a remarkable demonstration of solidarity, given the illegal nature of the action, and the lack of certainty that the refusal to sail would be general. Men were watching the other ships warily. Most attention was focussed on Valiant. Her seamen had refused to work the main derrick, and a party of Royal Marines had only succeeded in partially raising the picquet boat before they gave up the attempt, dropped the guys and joined the other men in revolt, leaving the boat hanging in mid air ${ }^{99}$ Cheering had already broken out among the crew of the Rodney massed on the forecastle and this was answered by 200 or more $\mathrm{Hood}$ ratings who had remained on the forecastle at the end of the breakfast period. Then at $8.00 \mathrm{a} . \mathrm{m}$., as colours were hoisted in all ships and with Valiant's preparations for sea still visibly incomplete, there was simultaneous cheering by ratings throughout the fleet. The mutiny proper had begun and other ships now joined in.

Admiral Tomkinson wired the Admiralty that the bulk of the men due to sail had refused duty and that he had recalled to harbour the ships at sea. Now for the first time the Admiralty replied, but only after a two hour delay, and only to indicate approval of his action and to urge officers to stress that great sacrifices were being required from all classes of the community. ${ }^{100}$ As Divine comments, "Bromidic at a time when the fleet had reached the point of total defiance, it can scarcely have hoped to achieve a return to discipline." 101

Between 8.00 a.m. and 9.30 a.m. on Tuesday was the high point of the mutiny. The immediate objective had been achieved, the fleet had been prevented from sailing. But beyond this objective aims were vague. The men expected a response of some sort from the Admiralty and most men would have settled for an early announcement that pay cuts would be limited to 10 per cent. In the mean time the crews pursued their action in different ways, again reflecting the fragmented nature of the protest. In the Hood and Nelson the general feeling seems to have been that the measures already taken were sufficient and that it was now proper to return to work according to normal harbour routine. ${ }^{102}$ From mid morning onwards a similar course was followed in Dorsetshire, and York's hands worked normally throughout the day. By contrast no work was done at all in Valiant, Rodney or Norfolk, and the numbers working in Adventure dropped off as the day progressed. Generally speaking on these latter ships

\footnotetext{
99 Day, interview of August 1976; Drage, Diary, September 15, 1931.

100 Invergordon - Copies of Signals.

101 Divine, Mutiny at Invergordon, p. 160.

102 Pursey, interview of January 23, 1974.
} 
ratings remained on the forecastle for much of the day, occasionally cheering the other ships in a demonstration of solidarity and as a way of exhorting other crews to join in the show of defiance. But cheering was effectively limited to ships adjacent to each other in the line, such as Rodney and Hood or Adventure and Valiant. Suggestions sometimes made that there were signal cheers between Nelson and Rodney at opposite ends of the line with six ships in between are not credible. ${ }^{103}$

Though technically a mutiny, what had really occurred was a strike. Naval Intelligence was later quick to follow up the possibility that the use of the strike weapon was related to trade-union influence. The Devonport-based ships, especially Rodney, Adventure and Norfolk, were judged to have been among the worst affected, and the Director of Naval Intelligence pointed out that 45 per cent of the men from this division came from the Midlands and the North. ${ }^{104}$ The point is certainly not without relevance, men were well aware of the practices of industrial workers, though to suggest a direct link between the proportion of Devonport ratings born north of a line from Bristol to London and the behaviour of their ships at Invergordon is clearly too simple. The tendency for an increasing number of ratings to come from Northern industrial towns and urban districts remote from the traditional naval catchment area of the Southern home ports and hinterland had been general since the turn of the century and was accompanied by a distinct change in the mentality of the lower deck. ${ }^{105}$

Men certainly knew about strikes, but this one was adapted by sailors to suit naval conditions. Collective refusals of duty were not unknown in the Service and from time to time when a ship's crew had been pushed too hard, perhaps while coaling ship or forced to do some non-essential work on a Sunday, they would simply go below, close the hatches and fail to turn out for duty in the afternoon. A well-publicised incident of this nature had occurred at Devonport earlier in 1931 involving the submarine depot ship Lucia. On Sunday January 4th, following several days of working under pressure, the hands refused to come on deck for duty after lunch and locked themselves below. 27 men were arrested, Leading Seaman William Carter was dismissed the Service, and four others were court-martialled with sentences of up to six months' hard labour handed down. A storm of public protest led to the sentences being commuted, but Carter's discharge

103 Again this is important for an appraisal of the conspiracy theory, since at various times these two have both been branded as lead ships.

104 Report of Director of Naval Intelligence.

105 See Carew, The Lower Deck Reform Movement. 
stood. ${ }^{106}$ The Lucia incident was fresh in the minds of the lower deck at Invergordon. ${ }^{107}$ Now men simply stayed on their messdecks or massed on the forecastle. As AB Fred Copeman comments,

The action was a simple affair, worked out in the simple way that comes natural to sailors. Go on the forecastle. If you're on the forecastle no one else can get there. The hatches from the seamen's mess deck lead directly to the forecastle. If the marines are with you no one can do anything about it. Every ship did it the same. The mutiny was a spontaneous, common sense form of action. It wasn't planned. 108

The action at Invergordon is also better described as a "strike" in the sense that the men made no attempt to take over the running of the ships. Even on the worst-affected vessels essential tasks were performed. Care and maintenance work was done, the decks were kept clean, duty boats were manned and stokers attended to auxiliary engines. In some ships men would turn up for work for a while and then disappear. The main objective was to stay clear of officers and if possible avoid being given a direct individual command to do something, refusal of which could be construed as a serious offence. For this purpose many ratings found it necessary to keep on the move and always out of the way. It was important for the men to maintain a united front and not to be singled out as individuals. Thus to a large extent they resisted invitations to see the captain to submit their circumstances for consideration as "hardship cases". To do so would be seen as a breach of solidarity. The general attitude was "we're all hardship cases". ${ }^{109}$ On some ships officers were detailed to select men to come forward to state their cases. Some men chosen in this way were afraid of reprisals from their messmates for having broken solidarity. Consequently officers found that when they went on to the mess decks or forecastle to try to talk to the hands the men would turn their backs and walk away. But otherwise officers were treated with respect.

The anticipated quick response from the Admiralty was not forthcoming. In the course of Tuesday afternoon Tomkinson sent a long signal to the Admiralty detailing the main points of the men's grievance, suggesting that the pay cuts for able seamen be reduced by half and urging an early decision on this matter. Yet again there was a six-hour delay before the Admiralty replied that it would consider "representations of hardship",

106 Hampshire Telegraph, January 23, 1931: House of Commons Debates, January 28, cc. 949-50; Owen, Insubordination and Mutiny, Vol. II, ch. 1. pp. 28-29. Adm. 178/135.

107 Commander R. Rodger, interview of November 1974.

108 Copeman, interview of January 1974.

109 Pursey, interview of January 4, 1978. 
but in the mean time it expected the men to "uphold the tradition of the Service by loyally carrying out their duty". And shortly afterwards, oblivious to the fact that urgent action on its own part was in order, it signalled Tomkinson: "It is important that programme of exercises should be resumed as soon as your investigations are complete." ${ }^{110}$ As Divine observes, more than any other episode in this catalogue of misunderstanding this sentence demonstrates the divorce between the Admiralty and the fleet. ${ }^{111}$

Malaya, Warspite and Repulse were all at sea when the mutiny began, but had now returned to harbour and, together with York, were under pressure to join in the action. In the course of Tuesday night threats of reprisals if blacklegging continued reached York through duty-boats crews plying between the ships, and meetings of ratings on each of these four ships were held in the dark hours. Seamen from Warspite and Malaya decided that they would at least refuse to paint or clean the sides of the ship; Repulse's crew let it be known that they would not go to sea again if ordered, and York ratings decided to "follow the flagship", in other words to take their cue from the crew of the Nelson. Meanwhile the absence of any positive response from the Admiralty caused men who had returned to work on Tuesday to reappraise their position. Wednesday's newspapers carried a brief Admiralty statement which referred merely to "unrest among a proportion of lower ratings" and made no mention of the refusal to sail. It seemed that the Admiralty were trying to play down the seriousness of the situation and this caused ratings in the Hood to resume their strike action from mid Wednesday morning. ${ }^{112}$ Dorsetshire's crew were also contemplating stopping work again, and on both ships a "make and mend" 113 was announced in the afternoon to forestall any further overt protest action. As on Tuesday no work was carried out in Rodney, Valiant and Adventure.

But as the mutiny extended into the second day so did the resolve of many men begin to waver. The sense of isolation and the lack of communications had an unnerving effect. They were now involved in a very serious action and would have welcomed an outlet. The captain of Valiant sensed that some of his crew were becoming frightened and wanted to go back to work. In Norfolk, Valiant and York there was a belief that only intimidation was preventing some ratings from returning to duty. By

\footnotetext{
110 Invergordon - Copies of Signals.

11 Divine, Mutiny at Invergordon, p. 167.

112 Pursey, "Invergordon - First Hand, Last Word", loc. cit., p. 162

113 In effect a free afternoon.
} 
contrast the passage of time was making other men more insistent that some revision of pay scales was necessary if the mutiny was to end. The captain of Nelson detected a hardening of attitudes mixed with a certain mistrust of the intentions of the other ships. The longer the mutiny lasted the more prone were the ratings to splits and division. They had prevented the ships from sailing, but thereafter the initiative lay with the Admiralty. All the men could do was to respond to Admiralty moves, and there was no way that their response could be concerted. Thus when at 2.45 p.m. on Wednesday the Admiralty finally caught the sense of urgency and ordered a return to home ports, where hardship cases would be looked into, the mutineers were in no position to improvise a united response. The announcement split the lower deck, provided those who wanted it with a means of getting off the hook and effectively took the steam out of the mutiny.

Even so the "return home" signal was greeted with considerable mistrust. Many regarded it as a ruse to break the mutiny and a means of separating the ships. Once away from Invergordon it was feared they might be dispersed to Scapa Flow or Spithead, where they would be boarded by armed marines and dealt with severely. On some ships for an hour or so following the announcement of the order the atmosphere was tense as ratings debated whether or not to obey. More militant sailors attempted to hold the line and for a time there appeared to be a majority in favour of staying put. Actual fighting broke out among stokers on the Norfolk over whether to abide by the order. ${ }^{114}$ Shouts of "No, No" from some ratings on the decks of Hood and Norfolk were an attempt to communicate to other ships their continued unwillingness to sail, while in Dorsethire efforts were made to induce communications ratings who had remained at work to join in the action even at this late hour. The rear-admiral commanding the battleships had grave doubts as to whether Valiant would sail and her captain made preparations to use force. By 6.30 p.m. it was still doubtful whether Nelson would be able to put to sea. William Pigge, an able seaman, had lashed the port-anchor cable to prevent her unmooring and the stokers had not yet gone below to raise steam. The captains of Nelson and Hood were both prepared to part their cables if ratings prevented the anchors from being weighed. But "leave and loved ones" at the home ports was a tempting prospect, and bit by bit support for continued resistance ebbed away. Some ships were visible preparing to put to sea and in view of this the ratings on the more militant ships drifted back to work. There was no

114 Jowett, interview of December 1973. 
clear-cut decision as such to return to duty, and some of the supposed leaders were back at work while their followers continued to hold out. ${ }^{115}$ By 7.00 p.m. the crew of Valiant, the first ship to mutiny, had fallen in for work, and psychologically this tipped the balance. The mutiny was effectively over. At 9.30 p.m. the cruiser squadron sailed on schedule, and an hour and a half later the battleships put to sea for home ports.

What, then, can be said about the organisation of the mutiny? The evidence clearly suggests that there was no central co-ordination. The success of the mutiny in forcing the Government to re-appraise the pay cuts was not based on any grand strategy, but stemmed from the deep feeling of injustice that was universal among ratings and a general acceptance that some form of protest had to be made. The refusal of duty was the simplest and most natural form of action they could take. Nevertheless individual sailors have made claims to overall leadership of the mutiny, arguing that the canteen meetings were where the grand design was planned. The version that has most currency holds that $\mathrm{AB}$ Leonard Wincott of HMS Norfolk led the protest. Wincott was subsequently discharged from the Navy and shortly afterwards joined International Labour Defence, a front organisation for the Communist Party. ${ }^{116}$ In November 1931 ILD produced a pamphlet on Invergordon setting out Wincott's claim to leadership and appealing for contributions for an "Invergordon Defence Committee". ${ }^{117}$ The mutiny was now an important element in Communist Party propaganda. Wincott was soon to join the party proper and as such was an important acquisition at a time when its fortunes were low. To represent Wincott as the leader of the mutiny at public meetings up and down the country reflected well on the party and raised its standing within the Comintern. And not without importance too, the notion of central leadership of the mutiny corresponded well with Leninist principles of revolutionary organisation. Thus the Admiralty's predisposition to view the mutiny as the work of ringleaders was complemented by the Communist Party's claim to have the support of the ringleader-in-chief. ${ }^{118}$

115 Drage, Diary, September 16, 1931. AB Riggs had the distinction of being the last man to return to duty on HMS Norfolk, but he does not figure in the list of "ringleaders" compiled by Naval Intelligence.

116 Barry Duncan. letter to Tribune, August 30, 1974.

117 The Spirit of Invergordon. Wincott now admits that he did not write the pamphlet and probably did not read it before it was published, interview of July $24,1974$.

118 The Admiralty's view was largely based on Wincott's version as retailed second-hand by AB Terry Gentry, an informer. Owen, Insubordination and Mutiny; Len Wincott, Invergordon Mutineer, (London, 1976), ch. 13. 
Without doubt Wincott was accepted by some of his fellow seamen on the Norfolk as a spokesman, and apart from speaking in the canteen on the Sunday evening his other claim to fame at Invergordon is that he had a hand in drafting a short manifesto from the Norfolk on the first morning of the mutiny. Actual authorship of the manifesto is somewhat in doubt since Wincott, Fred Copeman, George Hill who typed it and Commander Rodger whose typewriter was used all have conflicting recollections of how it came to be written. ${ }^{119}$ What is not in dispute is that outside the Norfolk it was not seen in the fleet and had no effect on the course of the mutiny. A copy was sent ashore to the Daily Herald correspondent in Invergordon and the Herald published it the day after the mutiny ended with ships once again at sea.

The fact is that in most ships there were numbers of ratings who played a prominent part in the affair: in Nelson Stoker Arthur Harwood and AB John Emerson; ABs George Day and Marshall Brockway of the Valiant; Stoker Alfred Fowler, Bandsman V. Alley and ABs Bond and Ryder from Rodney; Stoker Tom Winstanley and AB A. McConbray of Warspite; Leading Telegraphist Richard Athey of Dorsetshire together with Leading Seaman Dick Carr and ABs Copeman and Hill of Norfolk. These and many others helped to generate support for the action and to maintain the commitment once the mutiny had begun. But most of them were unacquainted with one another, and none of them was widely known or had any influence outside his own ship or even his own department. Different groups of sailors would take their cue from different "leaders". Among Valiant seamen, for example,George Day and Marshall Brockway clearly had their own distinct cliques. ${ }^{120}$

The main agitators were a mixed bunch of characters thrust forward by circumstances. Some were men who simply did not want to be in the Navy. Copeman had already applied for his discharge to join the police. ${ }^{121}$ There were also natural rebels such as Tom Winstanley. He had already acquired a reputation for leading a demonstration on the Revenge the previous year when there had been a deliberate mass breaking of leave accompanied by some desertions at Golfe Juan in France in protest against the disciplinary approach of the captain. For this Winstanley had been disrated from leading stoker. ${ }^{122}$ But there were also quieter men among them, family men

119 Interviews with Wincott of July 24, 1974, Copeman of January 1974 and Rodger of November 1974; letter from Hill, August 14, 1974.

120 Letters from F. J. Brooks, July 24, 1973, and W. G. Reid, August 31, 1973.

121 Copeman, interview of January 1974.

122 Letters from J. Malyon, March 22, 1978, and A. L. Colton, March 23, 1978; Captain of HMS Revenge to C-in-C Devenport, December 9, 1931, Adm. 178/112. 
who had invested many years in the Service, had much to lose and would not have engaged in the protest action lightly.

Altogether Naval Intelligence compiled a list of 120 men throughout the fleet who had been prominently involved at Invergordon. Twenty of them were leading hands or Royal Marine NCOs. Fifty-one had seen war service, meaning that they were personally acquainted with the pitifully low pre-Jerram scales of pay and knew about the struggle to have the pay improved in 1919. Nine of them had actually joined the Service before 1914 and had seen the rise of the lower-deck reform movement and the earlier campaign for the establishment of some constitutional channel of lower-deck representation before the Admiralty. ${ }^{123}$ Try as they might to categorise these 120 into grades of subversive, Naval Intelligence was unable to draw up a list of central leaders. Some on the list were given five-star rating as agitators. One man, thought to have masterminded the action of the Portsmouth ships from on board Nelson, was code-named "Red Admiral", while his counterpart in Rodney was known to Intelligence as "Gandhi". But as the Director of Naval Intelligence admitted, "were they replaced there is little doubt that their places would be taken by the other men named", and so his blanket recommendation was that all on the list should be discharged or otherwise eliminated. ${ }^{124}$

Even the list of 24 ratings who were subsequently discharged from the Navy, "Services No Longer Required", was a thoroughly arbitrary selection and can by no means be taken to represent the principal mutineers. Since the First Lord of the Admiralty had earlier announced that none of the mutineers would be punished, the excuse for these discharges was that the men had continued to agitate on returning to home port. There is very little evidence of this; there was no trial, the men themselves denied the accusation, and strangely those selected for discharge were all from Plymouth. Yet the Admiralty had a list of other men from Chatham and Portsmouth who it claimed agitated both at Invergordon and also later at home ports, and for the most part these, including the so-called "Red Admiral", were left alone. It would appear that the Admiralty did not really believe the evidence produced by Naval Intelligence against those branded as ringleaders. ${ }^{125}$ It is hard to avoid the conclusion that the discharging of 24 ratings was simply a matter of expediency, deliberately delayed until after the 1931 General Election so as not to damage the

123 Invergordon Incident, Vol. I, September 1931, Adm. 178/112.

124 Director of Naval Intelligence, minute, September 29, 1931, Adm. 178/80.

${ }_{125}$ Quite possibly the Admiralty's decision in 1932 not to renew the appointment of the Director of Naval Intelligence was a reflection of this. Meeting of Sea Lords, January 1, 1932, Adm. 178/129. 
National Government, and undertaken in breach of Government promises of "no reprisals". 126

All signs point to the fact that after painstaking investigation the Admiralty was unable to uncover a central group of ringleaders, and the best explanation for this is that there were none. The mutiny was an improvised demonstration which, had the Admiralty acted swiftly, need only have lasted for an hour or so as the ratings thought it might. It was a natural form of protest undertaken automatically by a large body of men who had long deliberated over the problem of inadequate pay and whose consciousness of the problem was rooted in a collective experience of agitation for better pay which dated back well over ten years.

126 The discharges were made in the first week of November, but it seems likely that the decision in principle had been taken by mid October. Sir Vernon Kell to Director of Naval Intelligence, October 15, 1931, Adm. 1/8757/181. The General Election was held on October 28 and the Prime Minister gave his personal consent to their discharge. Invergordon Incident, September 1931, Vol. IV, Adm. 178/113. 